\title{
Structures and Anatomical Distribution of Oxygenated Diterpenes in the Australian Nudibranch Chromodoris reticulata by Suciati Suciati
}




\title{
Structures and Anatomical Distribution of Oxygenated Diterpenes in the Australian Nudibranch Chromodoris reticulata
}

\author{
Suciati, ${ }^{\mathrm{A}, \mathrm{B}}$ Lynette K. Lambert, ${ }^{\mathrm{C}}$ and Mary J. Garson ${ }^{\mathrm{A}, \mathrm{D}}$

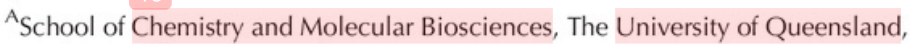 \\ Brisbane, QId 4072, Australia. \\ ${ }^{B}$ Faculty of Pharmacy, Airlangga University, Surabaya, East Java 60286, Indonesia. \\ ${ }^{C}$ Centre for Advanced Imaging, The University of Queensland, Brisbane, \\ Qld 4072, Australia. \\ ${ }^{D}$ Corresponding author. Email: m.garson@uq.edu.au
}

\begin{abstract}
The structures and stereochemistry of six new diterpenes (1-6), two of which contain cyclic imine functionality, have been deduced by 2D NMR spectroscopy. The anatomical distribution of these, and of 17 other diterpenes (7-23) that were also isolated, has been investigated. The known compound aplyroseol-2 (14) was the major compound in the mantle tissue along with some dialdehydes, while the linear furan ambliofuran (7) was the only diterpene found solely in the internal organs. The presence of lactone-acetal-hemiacetal functionality in many of the isolated compounds is a consequence of the reactive dialdehydes present in the mollusc.
\end{abstract}

Manuscript received: 21 January 2011.

Manuscript accepted: 16 March 2011.

\section{Introduction}

Nudibranchs from the order of Opisthobranchia (Mollusca: Gastropoda) are shell-less marine molluscs which lack physical defences against predation; and thus, may employ chemical defences to deter predators. They may be protected by metabolites obtained from dietary sources, commonly sponges, or from de novo biosynthesis. ${ }^{[1-4]}$ For example, a predator-prey interaction has been determined for Glossodoris atromarginata and its sponge diet that involves sesterterpene metabolites. ${ }^{[5]}$ Additionally, isotope-feeding studies have revealed the capability of dorid nudibranchs such as Dendrodoris limbata to produce terpenoids from mevalonic acid via de novo biosynthesis. ${ }^{[6-8]}$

Numerous diterpenes have been reported from chromodorid nudibranchs, ${ }^{[1,2,9]}$ and some of these metabolites show pronounced biological activity. ${ }^{[7,8,10-13]}$ Molinski and Faulkner isolated the aromatic norditerpenes macfarlandins $\mathrm{A}$ and $\mathrm{B},{ }^{[14]}$ closely related to aplysulfurin from Aplysilla sulfurea ${ }^{[15,16]}$ and macfarlandins C-E, related to metabolites found in Dendrilla sp., ${ }^{[17]}$ from Chromodoris macfarlandi. Their findings strongly suggested that $C$. macfarlandi may prey on two different sponges. ${ }^{[18]}$ The Golgi-modifying properties of macfarlandin

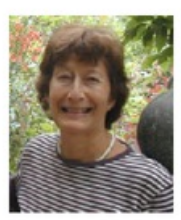

Professor Mary Garson is a Professor of Chemistry at The University of Queensland. She graduated from The University of Cambridge, UK with a Ph.D. (1977) and MA (1978), after which she undertook postdoctoral studies funded by a Royal Society of London Overseas Research Fellowship at the Universita Cattolica, Rome (1978). She then returned to Cambridge as a college research fellow and tutor at New Hall (since renamed as Murray Edwards College) within the university. Next she worked as a medicinal chemist in the UK pharmaceutical industry before emigrating to Australia following the award of a Queen Elizabeth II Research Fellowship at James Cook University of North Queensland (1983-1986). Prior to joining The University of Queensland as a lecturer in 1990, she held a lecturing position at The University of Wollongong in NSW. In her academic research, Professor Garson has made distinguished contributions to the fields of terrestrial and marine natural products, biosynthesis, and chemical ecology over a 30-year period. She is widely recognized for her collaborative research with colleagues from South-East Asian countries, including Thailand, Indonesia, and the Philippines. Professor Garson has been Chair of the International Relations Committee, as well as President of the Queensland branch, of the Royal Australian Chemical Institute. She was Executive Secretary of the team organizing the World Chemistry Congress in Brisbane in 2001, and is currently co-chair of the organizing committee for the 27th International Symposium on the Chemistry of Natural Products. From 2002 to 2004, she was chair of Australian Science Innovations (previously known as the Australian Science Olympiads). She is currently a Titular member, and honorary Secretary, of Division III (organic and biomolecular) of IUPAC, and the Division proposes to appoint her as Vice President (2012-13) succeeding to the Division Presidency in 2014-2015. An unusual form of professional recognition is that a new species of marine flatworm that she first collected at Heron Island has been named Maritigrella marygarsonae. 

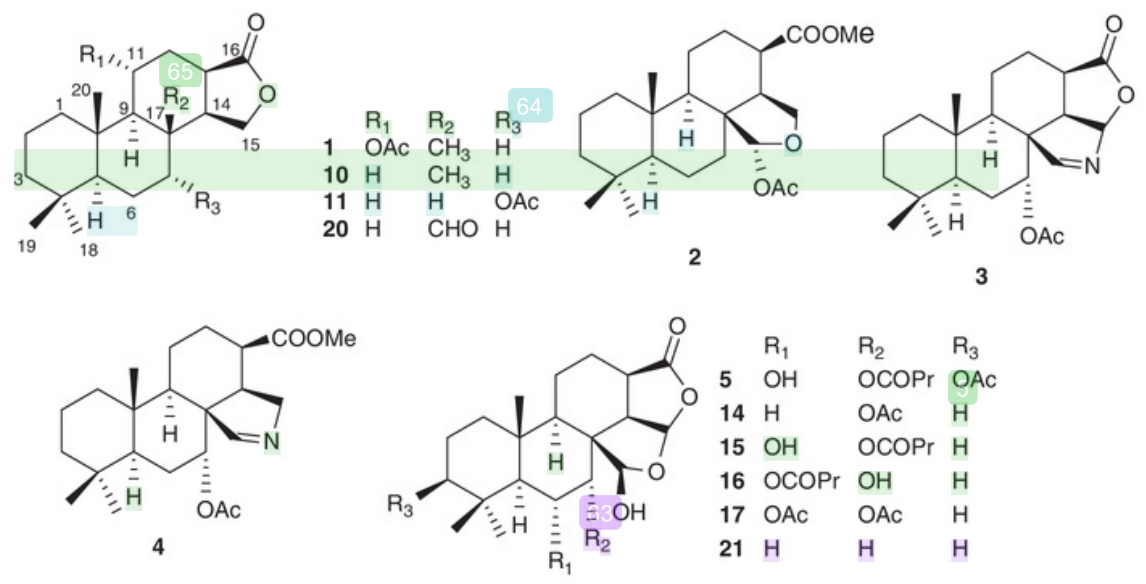

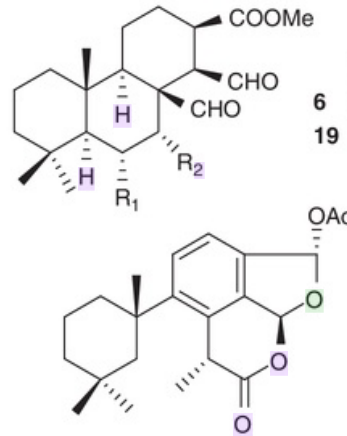

8

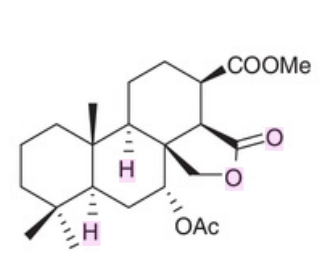

18

\section{$\begin{array}{lll}87 & R_{1} \\ R_{1} & R_{2}\end{array}$} $\mathrm{OH} \mathrm{OCOPr}$ $19 \mathrm{H}$ OAC OAc<smiles>COC(=O)[C@H](C)c1c([C@]2(C)CCCC(C)(C)C2)ccc2c1C(=O)OC2</smiles>

9<smiles>CC(C)=CCC/C(C)=C/CC/C(C)=C/CCc1ccoc1</smiles>

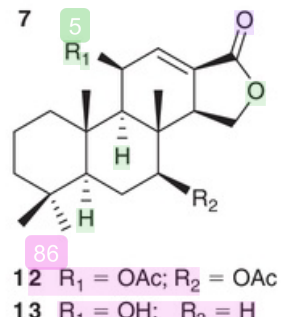

$13 \mathrm{R}_{1}=\mathrm{OH} ; \mathrm{R}_{2}=\mathrm{H}$<smiles>C[C@H]1CCC[C@]2(C)[C@@H]3C(=O)C=C4C(=O)OC[C@@H]4[C@@H]3CC[C@]12C</smiles>

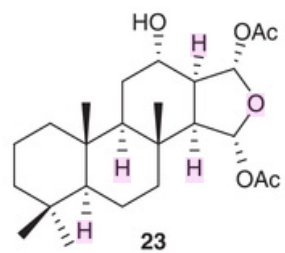

Fig. 1. Structures of diterpenoid metabolites isolated in the current study on the nudibranch Chromodoris reticulata.

E and of a synthetic analogue in which the hydroazuleno moiety is replaced by a tert-butyl group have been reported. ${ }^{[19]}$ Cell biological studies of the dynamics of Golgi organization are providing fundamental insight into how these organelles play a key role in protein modification within the cell. An intriguing question to address is how this biological activity may relate to the ecological roles of macfarlandin $\mathrm{E}$ in both the mollusc and its dietary sponge.

We report six new diterpenes (1-6) together with 17 known diterpenes (7-23) (Fig. 1) isolated from two specimens of Chromodoris reticulata. The anatomical distribution of the diterpene compounds within the various tissue types of the mollusc, was explored by dissection and analysis of one of the two specimens. The data are compared with our study ${ }^{[20]}$ on a specimen of a Chromodoris mollusc (species taxonomy possibly reticulata) which had earlier provided the two diterpenes 19 and
24, along with the four known metabolites 10, 14, 18, and 25 (Figs 1 and 2).

\section{Results and Discussion}

Two large specimens of Chromodoris reticulata were collected by SCUBA from the Gneerings Reef, offshore from Mooloolaba, in South East Queensland. One nudibranch was extracted with acetone to investigate the total chemistry and gave a terpene-rich organic extract that was fractionated by silica flash chromatography (hexanes/EtOAc), followed by normal phase HPLC (NP-HPLC) using hexanes/EtOAc. Using these separation protocols, three new (1-3) and 15 known metabolites were obtained. The known metabolites were identified by comparison of NMR data with the literature; these were ambliofuran (7), ${ }^{[21-23]}$ aplysulfurin $(\mathbf{8}),{ }^{[15,16]}$ membranolide (9), ${ }^{[24]}$ 


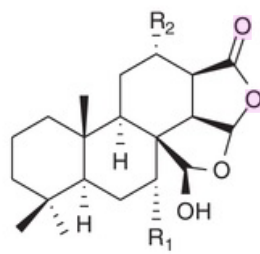

$\mathrm{R}^{2}$

$\begin{array}{lll} & \mathrm{R}_{1} & \mathrm{R}_{2} \\ \mathbf{2 4} & \mathrm{H} & \mathrm{OAC} \\ \mathbf{2 9} & \text { OCOPr } & \mathrm{H}\end{array}$<smiles>CC(=O)[C@H]1CC[C@@H]2[C@](C)(CC[C@@H]3[C@@H](C)CCC[C@]23C)[C@H]1C(=O)O</smiles><smiles>CC(=O)O[C@H]1C[C@@H]2C(=O)OC[C@H]2[C@H]2CC[C@H]3C(C)(C)CCC[C@]3(C)[C@H]12</smiles>

25

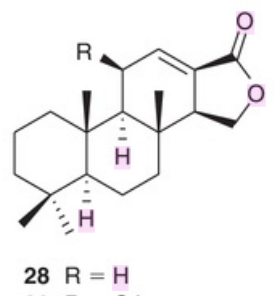

$30 \mathrm{R}=\mathrm{OAC}$

Fig. 2. Structures of diterpenoid metabolites isolated in earlier sponge or nudibranch studies, or from synthetic transformations.

spongian-16-one (10), ${ }^{[25]} 7 \alpha$-acetoxy-spongian-16-one (11), ${ }^{[22]}$ dorisenone $\mathrm{D}(\mathbf{1 2}),{ }^{[13]} \quad 11 \beta$-hydroxyspongi-12-en-16-one $(\mathbf{1 3}){ }^{[26]}$ aplyroseols-2, 3 and $5(\mathbf{1 4 - 1 6}),{ }^{[13,22,27]}$ dendrillol-2 (17), ${ }^{[23]}$ aplyroseol-9 $\left(=7 \alpha\right.$-acetoxydendrillol-3) $(\mathbf{1 8}),{ }^{[28]}$ the aldehydes $19^{[20]}$ and 20, ${ }^{[29]}$ and dendrillol-1 (21) ${ }^{[23]}$ Diterpenes 10,14 , and 18 were isolated in our earlier study on an unidentified chromodorid nudibranch. ${ }^{[20]}$ The second nudibranch was dissected to separate the mantle tissue from the internal organs in order to probe the distribution of individual metabolites. Extraction of the mantle tissue using the same procedure as for the first sample resulted in the isolation of three new diterpenes (4-6), while two additional compounds, namely spongi-12-en11,16-dione (22) ${ }^{[26]}$ and 12-deacetyl-aplysillin $(\mathbf{2 3}){ }^{[30]}$ were identified by comparison with literature data. All compounds isolated from the first specimen were also isolated from the second specimen.

Diterpene 1 displayed a sodiated molecular ion peak in the HR-ESI MS at $\mathrm{m} / z 385.2345$, corresponding to the molecular formula $\mathrm{C}_{22} \mathrm{H}_{34} \mathrm{O}_{4}$. Inspection of the NMR spectra (Tables 1 and 2) confirmed the presence of four methyl singlets $\left(\delta_{\mathrm{H}} 0.93\right.$, $0.91,0.86,0.82)$, and an acetate methyl $\left(\delta_{\mathrm{H}} 2.01\right)$, while two oxymethylene protons $\left(\delta_{\mathrm{H}} 4.31\right)$ were linked by HSQC to a carbon at $\delta_{\mathrm{C}} 67.6$, and showed $\mathrm{HMBC}$ correlations to a carbonyl at $\delta_{\mathrm{C}} 180.8$. These data suggested a spongian-16-one substituted with an acetate group, but when compared with $7 \alpha$-acetoxyspongian-16-one (11) ${ }^{[22]}$ the shift of the oxymethine proton $\left(\delta_{\mathrm{H}}\right.$ 5.17 for $\mathrm{H} 11$ in 1 compared with $\delta_{\mathrm{H}} 4.92$ for $\mathrm{H} 7$ of $\mathbf{1 1}^{[22]}$ ) supported a different substitution pattern. The 11-OAc was deduced by HMBC correlations from $\mathrm{H} 9$ and $\mathrm{H} 12 \alpha$ to $\mathrm{C} 11$, and confirmed by 1D TOCSY and COSY experiments. A boat conformation was inferred for ring $\mathrm{C}$, since $\mathrm{H} 13$ at $\delta_{\mathrm{H}} 2.90$ showed a large coupling $(J 11.5 \mathrm{~Hz})$ to $\mathrm{H} 12 \beta$ and so was axiallyorientated. Additionally, $\mathrm{H} 14$ and $\mathrm{H} 13$ were eclipsed, also showing an $11.5 \mathrm{~Hz}$ coupling; while an NOE between $\mathrm{H} 12 \beta$ and Me-17 supported the proposed conformation. ${ }^{[20,29,31]}$ In an alternative 'flattened' chair conformation, there would not be a large coupling between the equatorial $\mathrm{H} 13$ and either $\mathrm{H} 12$ proton, nor would an NOE between $\mathrm{H} 12 \beta$ and Me-17 be expected. Although such data must be used with care, an NOE between $\mathrm{H} 9$ and $\mathrm{H} 14$, but no equivalent $\mathrm{NOE}$ between $\mathrm{H} 11$ and
H13, suggested that the 11-OAc was $\alpha$-oriented. NOEs between $\mathrm{H} 11 / \mathrm{Me}-20$ and between $\mathrm{H} 11 / \mathrm{H} 1 \beta$ agreed with this interpretation. The $\beta$ orientation of $\mathrm{H} 11$ was consistent with a $J$ of $5.0 \mathrm{~Hz}$ between $\mathrm{H} 11$ and $\mathrm{H} 9$; a dihedral angle of $127.3^{\circ}$ was suggested by molecular modelling (Chem Bio 3D Ultra 12.0 (Cambridge)) using a MM2 force field for energy minimization to an RMS of 0.100 ). The data for 1 differed with the partial data reported for the synthetic $\mathbf{2 6}$ (with a $\beta-\mathrm{OAc}$ ), prepared by hydrogenation of a diterpene isolated from Spongia officinalis. ${ }^{[26]}$ Although we named 1 as $11 \alpha$-acetoxyspongian-16-one in view of its relationship to the known 10, we note that the 'spongianone' nomenclature prevalent in the literature for such lactones is unsatisfactory.

Diterpene 2 was obtained by NP-HPLC (hexanes/EtOAc, 80/ 20) and had the molecular formula of $\mathrm{C}_{23} \mathrm{H}_{36} \mathrm{O}_{5}$ inferred from HR-ESI MS $\left(m / z 415.2463[\mathrm{M}+\mathrm{Na}]^{+}\right)$. The ${ }^{1} \mathrm{H}$ NMR spectrum showed the presence of three methyl singlets $\left(\delta_{\mathrm{H}} 0.85,0.83\right.$, $0.78)$, an acetate methyl $\left(\delta_{\mathrm{H}} 2.11\right)$, a carboxymethyl $\left(\delta_{\mathrm{H}} 3.65\right)$, an acetal proton $\left(\delta_{\mathrm{H}} 6.44\right)$, and two oxymethylene protons $\left(\delta_{\mathrm{H}} 3.95,3.73\right)$. The data were similar to those of diterpene 27 , except for the oxymethylene proton signals instead of signals for a second acetal moiety. ${ }^{[29]} \mathrm{HMBC}$ correlations from the acetal proton $\left(\delta_{\mathrm{H}} 6.44\right)$ to $\mathrm{C} 7\left(\delta_{\mathrm{C}} 37.4\right)$ and the OAc $\left(\delta_{\mathrm{C}} 170.8\right)$ confirmed that the acetate group was attached to $\mathrm{C} 17$. The relative configuration of $\mathbf{2}$ was then explored. ${ }^{[20,31]} \mathrm{A}$ boat conformation was inferred for ring $\mathrm{C}$ since the axial $\mathrm{H} 13$ at $\delta_{\mathrm{H}} 2.79$ again showed a large coupling $(J 12.3 \mathrm{~Hz})$ to $\mathrm{H} 12 \beta$. A $5.7 \mathrm{~Hz}$ coupling between $\mathrm{H} 13$ and $\mathrm{H} 14$ matched with a dihedral angle of approximately $60^{\circ},{ }^{[29]}$ while the NOE between H9 and H13 agreed with the measured inter proton distance of $2.2 \AA$. Inspection of molecular models revealed that $\mathrm{H} 17$ would show an NOE to Me-20 irrespective of the C17 configuration. However, there was a strong NOE from $\mathrm{H} 17$ to the $\mathrm{H} 15$ proton $\left(\delta_{\mathrm{H}} 3.73\right)$ assigned as $\beta$ owing to the small coupling $(1.7 \mathrm{~Hz})$ with H14 that results from a dihedral angle close to $90^{\circ}$. The $\beta$ orientation of $\mathrm{H} 17$ was further confirmed by an $\mathrm{NOE}$ to $\mathrm{H} 11 \beta$, and by the shifts of $\mathrm{H} 7 \alpha$ and $\mathrm{H} 7 \beta\left(\delta_{\mathrm{H}} 1.36\right.$ and 2.35) that matched equivalent values in diterpene $27\left(\delta_{\mathrm{H}} 1.39\right.$ and 2.54$)$. This latter metabolite was previously isolated from the nudibranch Ceratosoma brevicaudatum, ${ }^{[29]}$ now considered a species of the genus Chromodoris. ${ }^{[2]}$ 


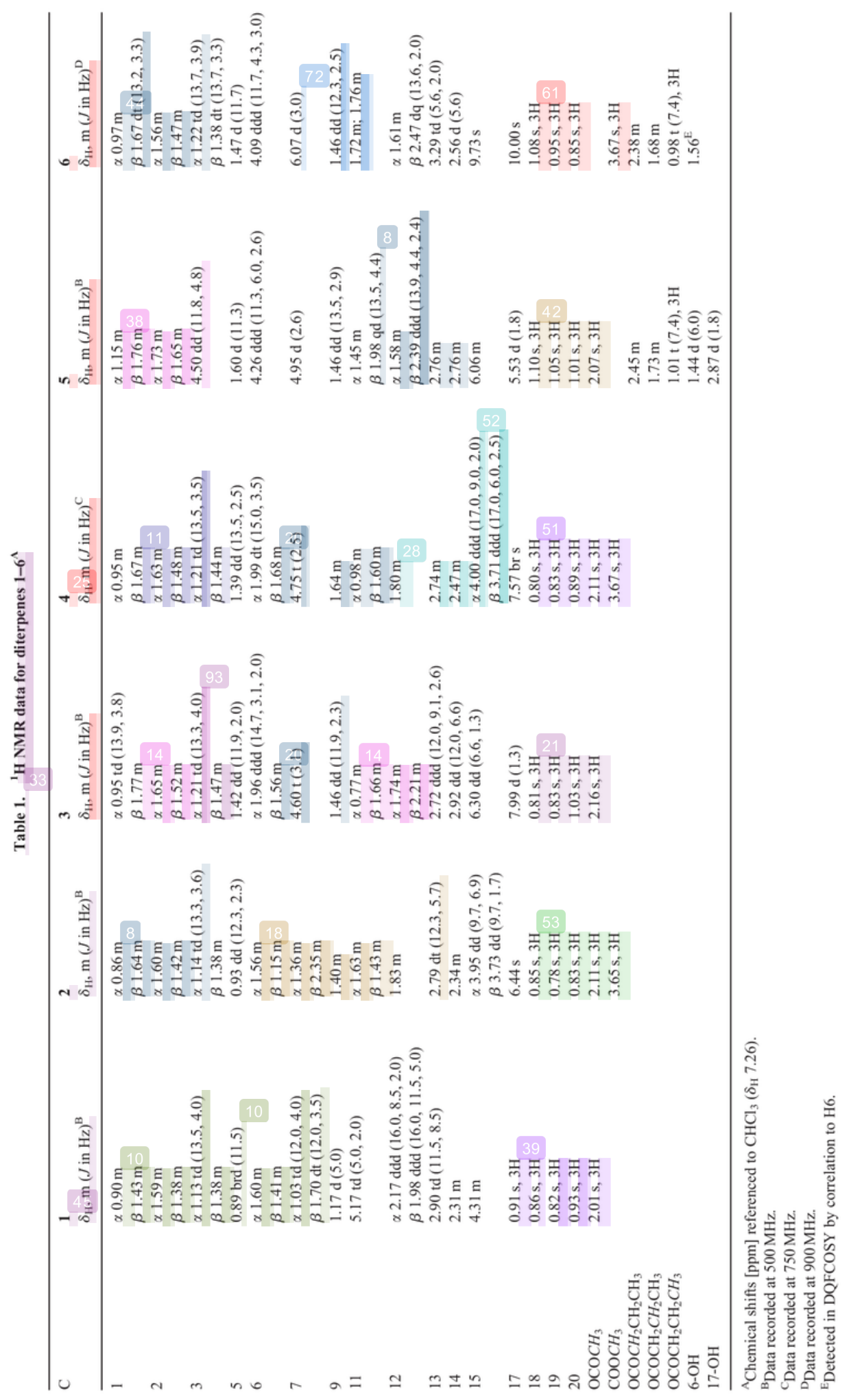


Table 2. ${ }^{13} \mathrm{C}$ NMR data for diterpenes $1-6^{\mathrm{A}, \mathrm{B}}$

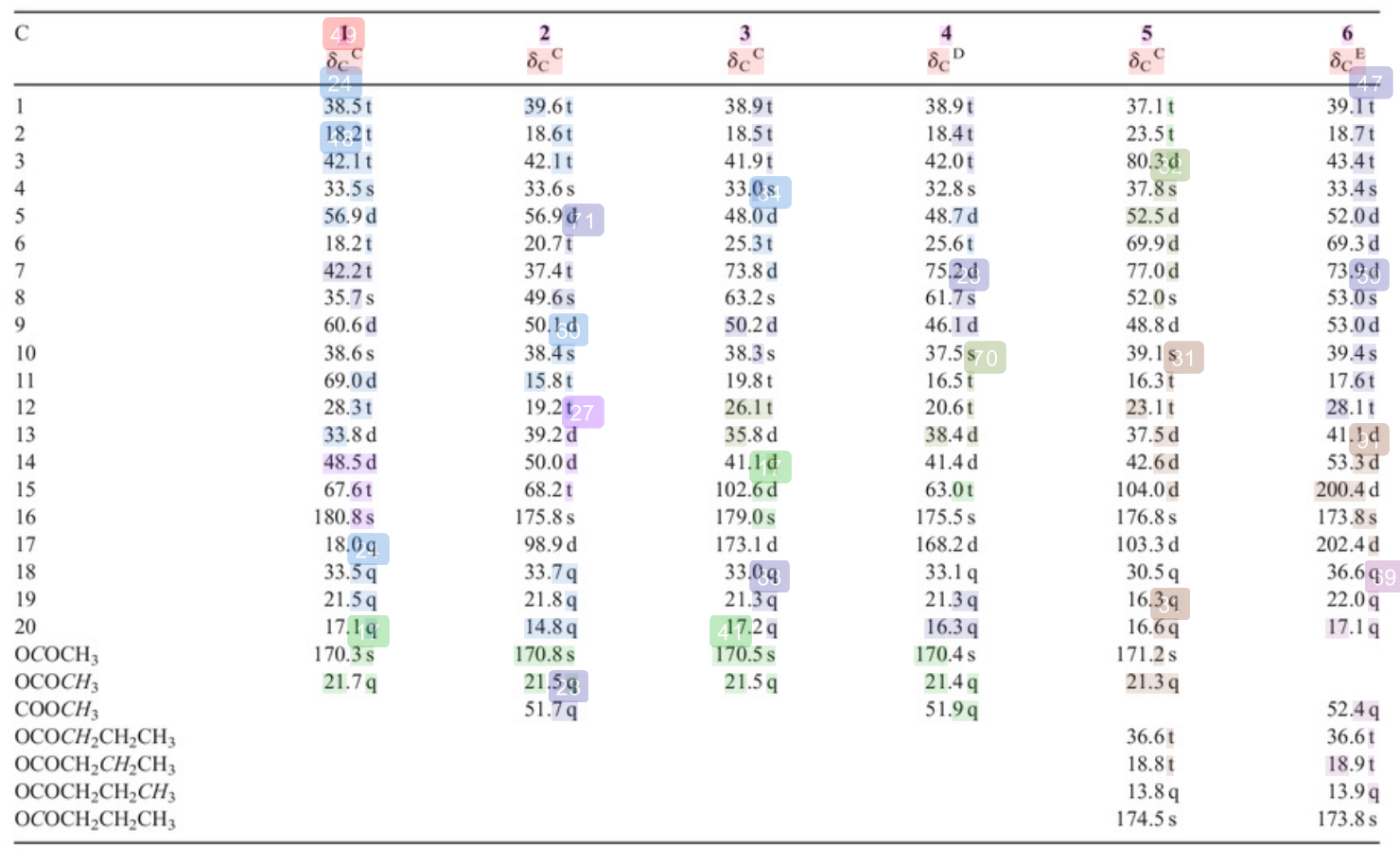

${ }^{\mathrm{A}}$ Chemical shifts $[\mathrm{ppm}]$ referenced to $\mathrm{CDCl}_{3}\left(\delta_{\mathrm{C}} 77.16\right)$.

${ }^{\mathrm{B}}$ Some assignments by HMBC experiments.

${ }^{\mathrm{C}}$ Data recorded at $125 \mathrm{MHz}$.

${ }^{\mathrm{D}}$ Data recorded at $188 \mathrm{MHz}$.

${ }^{\mathrm{E}}$ Data recorded at $225 \mathrm{MHz}$.

Diterpene 3 was obtained as a colourless oil by NP-HPLC (hexanes/EtOAc, 60/40), and had a molecular formula of $\mathrm{C}_{22} \mathrm{H}_{31} \mathrm{NO}_{4}$ inferred from HR-ESI MS ( $\mathrm{m} / z \quad 396.2147$ $[\mathrm{M}+\mathrm{Na}]^{+}$). The ${ }^{1} \mathrm{H}$ spectrum (Table 1) revealed three methyl singlets $\left(\delta_{\mathrm{H}} 1.03,0.83,0.81\right)$ and an acetate methyl $\left(\delta_{\mathrm{H}} 2.16\right)$ signals, which were similar to those found in aplyroseol-2 (14) ${ }^{[22]}$ but there was only one acetal proton $\left(\delta_{\mathrm{H}} 6.30\right)$ observed. A downfield signal $\left(\delta_{\mathrm{H}} 7.99\right)$ linked to a ${ }^{13} \mathrm{C}$ signal at $\delta_{\mathrm{C}} 173.1$ by HSQC suggested an imine. ${ }^{[32]}$ This was positioned at $\mathrm{C} 17$ from $\mathrm{HMBC}$ cross-peaks from $\delta_{\mathrm{H}} 7.99$ to $\mathrm{C} 8\left(\delta_{\mathrm{C}} 63.2\right), \mathrm{C} 14\left(\delta_{\mathrm{C}} 41.1\right)$ and the acetal at $\mathrm{C} 15\left(\delta_{\mathrm{C}} 102.6\right)$, and from a COSY correlation between $\mathrm{H} 15$ and $\mathrm{H} 17$. A 7-OAc group was determined by $\operatorname{COSY}\left(\mathrm{H} 7 / \mathrm{H}_{2} 6\right)$ and HMBC correlations ( $\mathrm{H} 7$ to $\mathrm{C} 5$ and the acetate carbonyl). The appearance of $\mathrm{H} 13$ differed from that in either $\mathbf{1}$ or $\mathbf{2}$; there was clearly a $12.0 \mathrm{~Hz}$ coupling between $\mathrm{H} 13$ and $\mathrm{H} 14$, suggesting they were eclipsed. The $J$ value of $9.1 \mathrm{~Hz}$ between $\mathrm{H} 13$ and $\mathrm{H} 12 \beta$ was smaller than that observed in either 1 or 2 , but is too large to be anything other than an axial-axial coupling as evidenced by a coupling between $\mathrm{H} 13$ and the equatorial $\mathrm{H} 12 \alpha$ of $2.6 \mathrm{~Hz}$. As in 1, but in contrast to 2, there was no evidence of an NOE between $\mathrm{H} 9$ and $\mathrm{H} 13$ for which an inter proton distance of $3.1 \AA$ was measured by modelling. The presentation of the $\mathrm{H} 13$ signal was also inconsistent with an alternative conformation, in which ring $\mathrm{C}$ adopts a flattened chair shape, for which models revealed that $\mathrm{H} 13$ would show similar-sized couplings to each of the H12 protons. The NOEs from $\mathrm{H} 14$ to each of $\mathrm{H} 9, \mathrm{H} 13$, and $\mathrm{H} 15$, established these protons on the bottom face of the rigid C-D-E ring system, an NOE from $\mathrm{H} 17 / \mathrm{Me}-20$ supported the configuration at $\mathrm{C} 8$, and NOEs from $\mathrm{H} 7 \beta$ to both $\mathrm{H} 17$ and $\mathrm{H} 15$ confirmed the $7 \alpha$-OAc.

The molecular formula of diterpene 4 was $\mathrm{C}_{23} \mathrm{H}_{35} \mathrm{NO}_{4}$ by HR-ESI MS, with the presence of nitrogen again suggesting an imine, as in 3 . The ${ }^{1} \mathrm{H} /{ }^{13} \mathrm{C}$ NMR and $\mathrm{HMBC}$ data also revealed a carbomethoxy group at $\mathrm{C} 13$ (as in 2 ) and an acetate group at $\mathrm{C} 7$ (as in 3). Compared with $\mathbf{3}$, the acetal proton at $\mathrm{C} 15$ was replaced by signals for a diastereotopic methylene $\left(\delta_{\mathrm{H}} 4.00,3.71\right)$. H15 $\beta$ showed $\mathrm{HMBC}$ correlations to $\mathrm{C} 13$ and there were also $\mathrm{HMBC}$ correlations from $\mathrm{H} 13$ and $\mathrm{H} 14$ to $\mathrm{C} 15$. The $\mathrm{C} 17$ imine at $\delta_{\mathrm{C}} 168.2$ had $\mathrm{HMBC}$ correlations with $\mathrm{H}_{2} 15$ and $\mathrm{H} 9$, while there was also a long range COSY correlation from both $\mathrm{H} 15$ signals to $\mathrm{H} 17$ at $\delta_{\mathrm{H}} 7.57$. The NOE correlations observed between $\mathrm{H} 13 / \mathrm{H} 9, \mathrm{H} 13 / \mathrm{H} 14, \mathrm{H} 7 / \mathrm{H} 14, \mathrm{H} 7 / \mathrm{H} 17$ confirmed the $\alpha$ orientations of $\mathrm{H} 13, \mathrm{H} 14$, and the 7-OAc group. To our knowledge, imine functionality, as seen in $\mathbf{3}$ and $\mathbf{4}$, has not been encountered in this class of compound before. Unfortunately attempts to reduce the imine moiety using $\mathrm{H}_{2} / \mathrm{Pd}-\mathrm{C}$ gave multiple products that could not be definitively characterized given the small amounts of product available. We named the new diterpenes $\mathbf{3}$ and $\mathbf{4}$ as chromoculatimine A and B, respectively.

Diterpene 5 was isolated as a colourless oil that gave a $[\mathrm{M}+\mathrm{Na}]^{+}$ion at $m / z 517.2397$ in the HR-ESI MS, matching the molecular formula $\mathrm{C}_{26} \mathrm{H}_{38} \mathrm{O}_{9}$. The ${ }^{1} \mathrm{H}$ and ${ }^{13} \mathrm{C}$ NMR spectra showed evidence for three methyl groups $\left(\delta_{\mathrm{H}} 1.10,1.05,1.01\right)$, a butyrate ester $\left(\delta_{\mathrm{H}} 2.45,1.73,1.01 ; \delta_{\mathrm{C}} 174.5 \mathrm{~s}, 36.6 \mathrm{t}, 18.8 \mathrm{t}\right.$, 


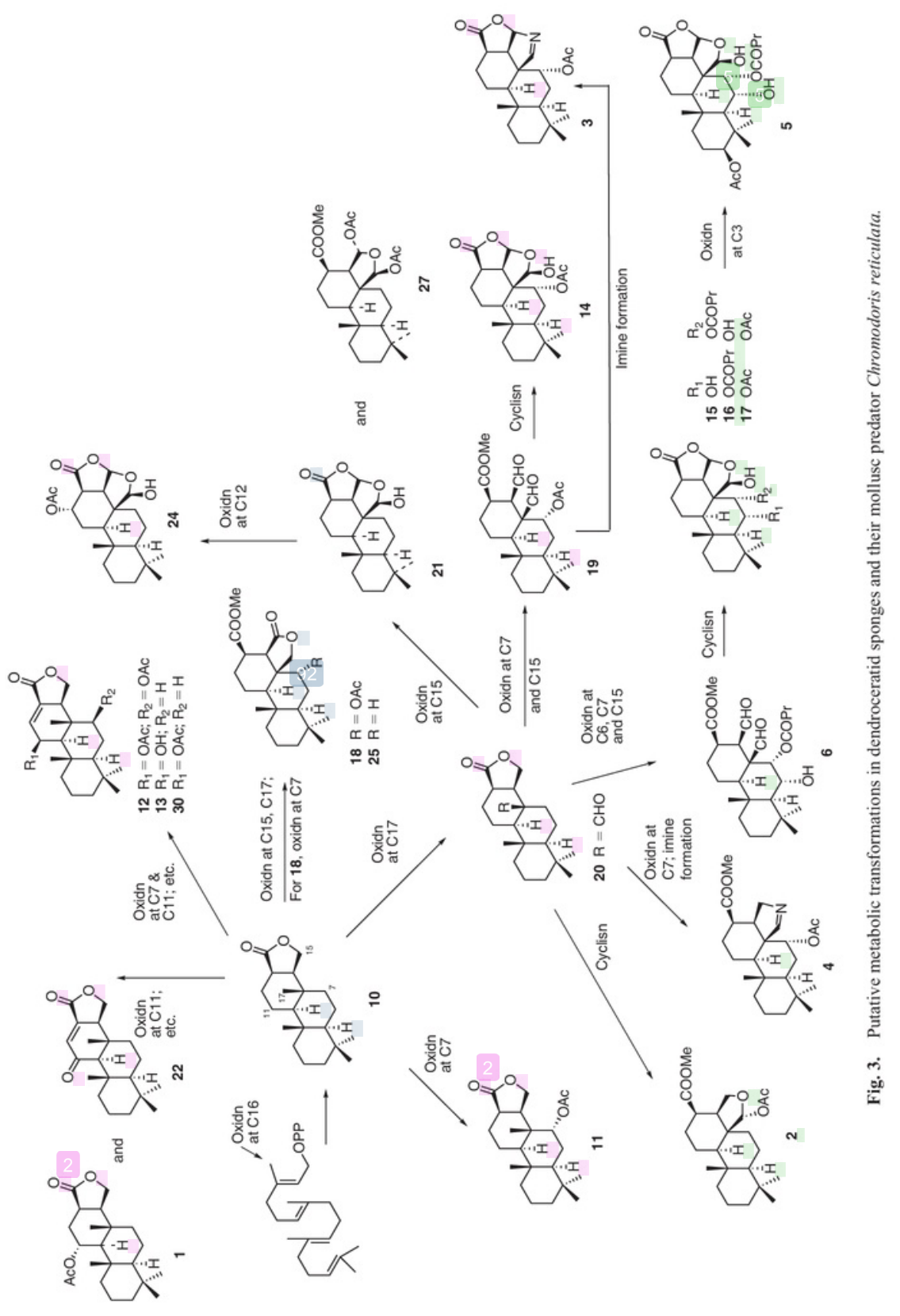


$13.8 \mathrm{q})$, an acetate methyl $\left(\delta_{\mathrm{H}} 2.07, \delta_{\mathrm{C}} 21.3\right)$, and two acetal groups $\left(\delta_{\mathrm{H}} 6.06,5.53 ; \delta_{\mathrm{C}} 104.0,103.3\right)$. These structural features were similar to those seen in the aplyroseol series of metabolites, ${ }^{[13,22,23,27]}$ notably aplyroseol-3 (15), ${ }^{[22]}$ except there was an additional oxymethine signal at $\delta_{\mathrm{H}} 4.50$ for $\mathrm{H} 3$ that appeared as a doublet of doublets $(J 11.8,4.8 \mathrm{~Hz})$ revealing the axial position of $\mathrm{H} 3$, and hence a $\beta$ orientation for the $\mathrm{C} 3$ substituent, that was further confirmed by NOESY correlations from $\mathrm{H} 3$ to $\mathrm{H} 1 \alpha, \mathrm{H} 5$, and $\mathrm{Me}-18$. HMBC, COSY, and 1DTOCSY experiments revealed that the acetate, hydroxyl, and butyrate ester groups were attached to $\mathrm{C} 3, \mathrm{C} 6$, and $\mathrm{C} 7$, respectively. The axial $\mathrm{H} 6$ at $\delta_{\mathrm{H}} 4.26$ (ddd, $J 11.3,6.0,2.6 \mathrm{~Hz}$ ) showed coupling to $\mathrm{H} 5\left(\delta_{\mathrm{H}} 1.60, \mathrm{~d}, 11.3\right)$, the equatorial $\mathrm{H} 7\left(\delta_{\mathrm{H}} 4.95, \mathrm{~d}\right.$, $2.6)$ and an $\mathrm{OH}\left(\delta_{\mathrm{H}} 1.44, \mathrm{~d}, 6.0\right)$. As in aplyroseol-3 (15), NOEs from $\mathrm{H} 17$ to $\mathrm{Me}-20, \mathrm{H} 6$, and $\mathrm{H} 7$ confirmed a $6 \alpha-\mathrm{OH}$, a $17 \beta-\mathrm{OH}$, and an $\alpha$-orientated butyrate group. Additional NOEs were between $\mathrm{H} 7 / \mathrm{H} 14$ and $\mathrm{H} 7 / \mathrm{H} 15$.

The HR-ESI MS of diterpene 6 displayed a sodiated molecular ion at $\mathrm{m} / \mathrm{z} 473.2508$ corresponding to a molecular formula $\mathrm{C}_{25} \mathrm{H}_{38} \mathrm{O}_{7}$. The ${ }^{1} \mathrm{H}$ and ${ }^{13} \mathrm{C}$ NMR spectra resembled those of the known aldehyde 19, ${ }^{[20]}$ and included three methyl singlets $\left(\delta_{\mathrm{H}} 1.08,0.95,0.85\right)$, a carboxymethyl $\left(\delta_{\mathrm{H}} 3.67 ; \delta_{\mathrm{C}} 52.4\right)$, and two aldehyde protons $\left(\delta_{\mathrm{H}} 10.00,9.73 ; \delta_{\mathrm{C}} 202.4,200.4\right)$. However, there was no acetate group present; instead there was a butyrate ester $\left(\delta_{\mathrm{H}} 2.38,1.68,0.98 ; \delta_{\mathrm{C}} 173.8 \mathrm{~s}, 36.6 \mathrm{t}, 18.9 \mathrm{t}\right.$, $13.9 \mathrm{q})$ and a hydroxy group $\left(\delta_{\mathrm{H}} 1.56\right.$, detected by DQFCOSY). The hydroxy group and butyrate ester were identified as attached to $\mathrm{C} 6\left(\delta_{\mathrm{H}} 4.09 ; \delta_{\mathrm{C}} 69.3\right)$ and $\mathrm{C} 7\left(\delta_{\mathrm{H}} 6.07 ; \delta_{\mathrm{C}} 73.9\right)$, respectively, by HMBC experiments. As in $\mathbf{1 9}$, both aldehydes were $\beta$ oriented since there were NOESY cross peaks from $\mathrm{H} 15$ to $\mathrm{H} 7$ and $\mathrm{H} 14$, and from $\mathrm{H} 17$ to $\mathrm{H} 6, \mathrm{H} 7$, and $\mathrm{Me}-20$. The $\alpha$ orientations of the butyrate ester and the hydroxy group were confirmed by NOEs between H6/Me-20, H6/Me-19, H6/H17, $\mathrm{H} 6 / \mathrm{H} 7, \mathrm{H} 7 / \mathrm{H} 15$, and $\mathrm{H} 7 / \mathrm{H} 17$.

Consistent $[\alpha]_{D}$ trends in this series of highly functionalized diterpenes are not readily apparent. In our earlier work, metabolite $\mathbf{2 4}$ was assigned to the same enantiomeric series as (+)-isoagatholactone (28), ${ }^{[33]}$ for which the absolute configuration has been established based on total synthesis from $(+)$-manool. In contrast, aplyroseol-1 (29), with the same absolute configuration deduced from an X-ray study, has a negative $[\alpha]_{D}$ value. ${ }^{[34]}$

Following the careful dissection and analysis of the second Chromodoris specimen, ${ }^{1} \mathrm{H}$ NMR spectra of extracts or fractions obtained from the mantle and internal organs were compared. The mantle tissue extract contained diterpenes 1-6, 9, 11-14, 16,17 , and 20-22, while ambliofuran 7 was found only in the internal organs. The remaining diterpenes $8,10,15,18,19$, and 23 were found in both tissue types. Aplysulfurin (8) was the major component in the internal organs, while aplyroseol-2 (14) was the major compound in the mantle tissue. As in our previous study, ${ }^{[20]}$ dialdehydes such as 19 were concentrated in the mantle tissue compared with the internal organs.

Based on the pattern of metabolites from this particular nudibranch, the dietary origin of these oxidised diterpenes could be dendroceratid sponges. ${ }^{[35]}$ As noted earlier, dialdehyde 19 provides acetal 14 directly on cyclization (Fig. 3); ${ }^{[20]}$ consequently new dialdehyde 6 could be the actual source of acetal 15 . Imine 3 may result from formal addition of ammonia (or equivalent) to dialdehyde 19 , while the absence of aldehyde functionality at $\mathrm{C} 15$ in e.g. 20 limits additional cyclization and leads to diterpene 2 or imine 4 , each with a free carbomethoxy group. In contrast, lactone $\mathbf{1 8}$ apparently results from oxidation of a dialdehyde at $\mathrm{C} 15$ and reduction at $\mathrm{C} 17$, or alternatively is the eventual product of incomplete oxidation of the $\mathrm{C} 17 \mathrm{Me}$ group in an earlier intermediate on the biosynthetic pathway. Lactones 1 and $\mathbf{1 1}$ may each derive from oxidation and acetylation of lactone 10, reactions which by analogy with the established chemistry of various Glossodoris molluscs ${ }^{[36]}$ might be expected to occur in the mollusc rather than the dietary source. However a related profile of oxidation-acetylation is also seen in lactones $\mathbf{1 2}$ and $\mathbf{1 3}$, structurally related to the known sponge compound 30 .

\section{Conclusion}

This study reported six new diterpenes (1-6) along with 17 known metabolites previously isolated from dendroceratid sponges and from the nudibranch $C$. obsoleta. Fifteen of these diterpenes were present only in mantle tissue, while seven of the remaining eight metabolites were present in both mantle and digestive tissues extracts. The linear furan ambliofuran 7 was the only diterpene found solely in the internal organs extract. The presence of lactone-acetal-hemiacetal functionality in many of the isolated diterpenes is likely related to dialdehyde precursors.

\section{Experimental}

General

Optical rotations were obtained using a Perkin-Elmer 241-MC polarimeter. 1D and 2D NMR spectra were acquired using Bruker Avance 500, 750, and 900 instruments. NMR spectra were obtained in deuterochloroform or benzene- $d_{6}$ at room temperature, and were internally referenced to $\mathrm{CHCl}_{3}\left(\delta_{\mathrm{H}} 7.26\right)$ or $\mathrm{C}_{6} \mathrm{H}_{6}\left(\delta_{\mathrm{H}} 7.16\right)$ and $\mathrm{CDCl}_{3}\left(\delta_{\mathrm{C}} 77.16\right)$ or $\mathrm{C}_{6} \mathrm{D}_{6}\left(\delta_{\mathrm{C}} 128.06\right)$. Positive ion electrospray mass spectra (LR-ES MS) were determined using a Bruker Esquire HCT instrument or (HR-ESI MS) using a MicroTof Q instrument each with a standard ESI source. Samples were introduced into the source using $\mathrm{MeOH}$ as solvent. NP-HPLC was carried out using a Waters 515 pump with a Waters $10 \mu \mu$ Porasil $7.8 \times 300 \mathrm{~mm}$ column and a Gilson 132 series RI detector with EtOAc/hexanes as solvent, flow rate $2 \mathrm{~mL} \mathrm{~min}{ }^{-1}$. Reverse phase HPLC was carried out using a Shimadzu LC-20AT pump with a Phenomenex Gemini $5 \mu \mathrm{C} 18$ $10 \times 250 \mathrm{~mm}$ column, and a Shimadzu ELSD-LT (low temperature evaporative light scattering detector), using $\mathrm{MeOH} /$ $\mathrm{H}_{2} \mathrm{O}$ as a solvent at flow rate $1.5 \mathrm{~mL} \mathrm{~min}^{-1}$.

\section{Collection, Extraction, and Isolation}

Two mollusc specimens were collected from Hanging Rock dive site, at the Inner Gneerings reef, a group of shoals near Mooloolaba (Australia), using SCUBA at a depth of $10-15 \mathrm{~m}$ on 5 December 2009. Subsequent examination revealed their identity was Chromodoris reticulata. ${ }^{[37]}$ The samples were taken back to the laboratory and stored at $-20^{\circ} \mathrm{C}$ until extraction.

A specimen of Chromodoris reticulata (wet weight $9.4 \mathrm{~g}$ ) was diced and extracted exhaustively with acetone by using ultrasonic vibration for $30 \mathrm{~min}$. The extract was removed, filtered through cotton, and concentrated under reduced pressure to give an aqueous residue, which was then partitioned with EtOAc. The organic layer was removed, dried over anhydrous $\mathrm{MgSO}_{4}$, and evaporated under reduced pressure to give a brown crude extract $(238 \mathrm{mg})$. The extract was then subjected to $\mathrm{SiO}_{2}$ flash chromatography with gradient elution (hexanes to EtOAc) to give 13 fractions. Compounds $7(0.9 \mathrm{mg}), \mathbf{1 0}(16.4 \mathrm{mg})$, and 
$14(74.2 \mathrm{mg})$ were identified in fractions 2,6 , and 10 , respectively. Fraction $7(31.4 \mathrm{mg})$ was subjected to NP-HPLC (hexanes/ EtOAc, 80/20) to afford the new compound $2(1.5 \mathrm{mg})$ and diterpene $8(6.6 \mathrm{mg})$. Fraction $8(10.5 \mathrm{mg})$ was subjected to reverse phase-HPLC using gradient elution of $\mathrm{MeOH} / \mathrm{H}_{2} \mathrm{O}(70$ / 30 ) to $100 \% \mathrm{MeOH}$ for $40 \mathrm{~min}$, and gave compounds $9(2.3 \mathrm{mg})$ and $11(1.5 \mathrm{mg})$. A fraction from the reverse phase-HPLC containing a mixture of compounds was subjected to NP-HPLC (hexanes/EtOAc, 75/25), and gave a mixture of compounds 13 and $21(1.8 \mathrm{mg})$, the new lactone $\mathbf{1}(<0.3 \mathrm{mg})$, and a mixture of lactone 11 and aldehyde $20(1.3 \mathrm{mg})$. Fraction $9(12 \mathrm{mg})$ was chromatographed on NP-HPLC (hexanes/EtOAc, 80/20) to afford compounds $12(0.4 \mathrm{mg})$ and $\mathbf{1 8}(0.3 \mathrm{mg})$. Fractions 11 and 12 were combined $(19.7 \mathrm{mg})$, and chromatographed on NPHPLC (hexanes/EtOAc, 60/40) to give aldehyde 19 (1.9 mg), a mixture of compounds 14 and 15 (6.3 mg), as well as compounds $\mathbf{1 7}(1.4 \mathrm{mg}), \mathbf{1 6}(3.1 \mathrm{mg})$, and the new imine $\mathbf{3}(1.8 \mathrm{mg})$, in order of elution.

The second specimen of Chromodoris reticulata (wet weight $7.8 \mathrm{~g}$ ) was dissected into mantle (wet weight $3.9 \mathrm{~g}$ ) and internal organs (wet weight $2.8 \mathrm{~g}$ ). Each section was extracted using the same procedure as for the first animal, to give an orange oil $(232 \mathrm{mg})$ from the mantle and a yellow oily extract $(66 \mathrm{mg})$ from the internal organs. The mantle extract was subjected to $\mathrm{SiO}_{2}$ flash chromatography with gradient elution (hexanes to EtOAc) to give 14 fractions. Fraction $9(15.0 \mathrm{mg}$, hexanes/EtOAc, $80 / 20)$ was subjected to NP-HPLC (hexanes/EtOAc, 80/20) to give lactone $22(0.3 \mathrm{mg})$. Fraction $12(37.0 \mathrm{mg}$, hexanes/EtOAc, $65 / 35$ ) was subjected to NP-HPLC (hexanes/EtOAc, 60/40) to afford compound $23(1.7 \mathrm{mg})$. Fractions 7 and 8 from the NPHPLC of fraction 12 were combined before further NP-HPLC (hexanes/EtOAc, $70 / 30)$ to give dialdehyde $6(\sim 0.2 \mathrm{mg})$. Fraction $13(12.8 \mathrm{mg}$, hexanes/EtOAc, 60/40) was also subjected to the same NP-HPLC conditions to give diterpene $5(0.5 \mathrm{mg})$, imine $3(0.9 \mathrm{mg})$, and imine $4(0.4 \mathrm{mg})$, in order of elution.

\section{1 $\alpha$-Acetoxy-spongian-16-one (1)}

Colourless oil; $[\alpha]_{\mathrm{D}}+73\left(\right.$ c 0.01 in $\left.\mathrm{CHCl}_{3}\right) ; \delta_{\mathrm{H}}\left(\mathrm{CDCl}_{3}\right.$, $500 \mathrm{MHz})$ and $\delta_{\mathrm{C}}\left(\mathrm{CDCl}_{3}, 125 \mathrm{MHz}\right)$, see Tables 1 and 2 ; $\delta_{\mathrm{H}}$ (benzene- $\left.d_{6}, 500 \mathrm{MHz}\right) 5.17(1 \mathrm{H}, \mathrm{td}, J 5.0,2.0 \mathrm{~Hz}, \mathrm{H} 11)$, $3.73(1 \mathrm{H}, \mathrm{dd}, J 10.0,2.1 \mathrm{~Hz}, \mathrm{H} 15 \beta), 3.56(1 \mathrm{H}, \mathrm{dd}, J 10.0,8.1 \mathrm{~Hz}$, $\mathrm{H} 15 \alpha$ ), 2.35 (1H, td, $J 11.0,8.8 \mathrm{~Hz}, \mathrm{H} 13), 2.23$ (1H, ddd, $J 16.0$, $8.8,2.1 \mathrm{~Hz}, \mathrm{H} 12 \alpha$ ), 1.89 ( $1 \mathrm{H}$, ddd, $J 11.0,4.8 \mathrm{~Hz}, \mathrm{H} 12 \beta), 1.70$ $\left(3 \mathrm{H}, \mathrm{s}, \mathrm{OCOCH}_{3}\right), 1.51(1 \mathrm{H}, \mathrm{m}, \mathrm{H} 14), 1.48(1 \mathrm{H}, \mathrm{m}, \mathrm{H} 1 \beta), 1.46$ $(1 \mathrm{H}, \mathrm{m}, \mathrm{H} 2 \alpha), 1.29(2 \mathrm{H}, \mathrm{m}, \mathrm{H} 7 \beta, \mathrm{H} 2 \beta), 1.25(1 \mathrm{H}, \mathrm{m}, \mathrm{H} 6 \alpha), 1.09$ $(1 \mathrm{H}, \mathrm{dt}, J 12.5,3.5 \mathrm{~Hz}, \mathrm{H} 3 \beta), 1.06(1 \mathrm{H}, \mathrm{m}, \mathrm{H} 7 \alpha), 1.01(1 \mathrm{H}, \mathrm{m}$, $\mathrm{H} 6 \beta), 0.88(1 \mathrm{H}, \mathrm{m}, \mathrm{H} 1 \alpha), 0.84(1 \mathrm{H}, \mathrm{d}, J 5.0 \mathrm{~Hz}, \mathrm{H} 9), 0.80(3 \mathrm{H}, \mathrm{s}$, $\mathrm{Me}-18), 0.71(3 \mathrm{H}, \mathrm{s}, \mathrm{Me}-19), 0.60$ (1H, dd, $J 12.4,2.5 \mathrm{~Hz}, \mathrm{H} 5)$, 0.60 (3H, s, Me-20), 0.49 (3H, s, Me-17), 0.41 (1H, m, H3 $\alpha$ ), assignment of $\mathrm{H} 2$ and $\mathrm{H} 6$ may be interchanged, $\delta_{\mathrm{C}}$ (benzene- $d_{6}$, $125 \mathrm{MHz}$, partial data from HSQC) $68.9(\mathrm{C} 11), 66.5(\mathrm{C} 15), 60.5$ (C9), 56.8(C5), 48.3 (C14), 42.2(C7), 41.6(C3), 38.6(C1), 33.4 (Me-18), 28.4 (C12), $21.3(\mathrm{Me}-19), 21.1\left(\mathrm{OCOCH}_{3}\right), 18.3(\mathrm{C} 2)$, 18.0 (C6), $17.4(\mathrm{Me}-17), 16.7(\mathrm{Me}-20)$, assignment of $\mathrm{C} 2$ and $\mathrm{C} 6$ may interchanged; HR-ESI MS m/z $385.2345[\mathrm{M}+\mathrm{Na}]^{+}$; calc. for $\mathrm{C}_{22} \mathrm{H}_{34} \mathrm{O}_{4} \mathrm{Na}$ : 385.2349

Methyl 15,17-Epoxy-17 $\alpha$-acetoxy-ent-isocopalan16-oate (2)

Colourless oil; $[\alpha]_{\mathrm{D}}+31\left(\right.$ c 0.10 in $\left.\mathrm{CHCl}_{3}\right) ; \delta_{\mathrm{H}}\left(\mathrm{CDCl}_{3}\right.$, $500 \mathrm{MHz})$ and $\delta_{\mathrm{C}}\left(\mathrm{CDCl}_{3}, 125 \mathrm{MHz}\right)$, see Tables 1 and 2 ;
HR-ESI MS $m / z 415.2463[\mathrm{M}+\mathrm{Na}]^{+}$; calc. for $\mathrm{C}_{23} \mathrm{H}_{36} \mathrm{O}_{5} \mathrm{Na}$ : 415.2455 .

\section{Chromoculatimine A (3)}

Colourless oil; $[\alpha]_{\mathrm{D}}-13\left(\mathrm{c} 0.09\right.$ in $\left.\mathrm{CHCl}_{3}\right) ;{ }^{1} \mathrm{HNMR}\left(\mathrm{CDCl}_{3}\right.$, $500 \mathrm{MHz})$ and ${ }^{13} \mathrm{CNMR}\left(\mathrm{CDCl}_{3}, 125 \mathrm{MHz}\right)$, see Tables 1 and 2; HR-ESI MS m/z 396.2147 [M+Na] $]^{+}$; calc. for $\mathrm{C}_{22} \mathrm{H}_{31} \mathrm{NO}_{4} \mathrm{Na}$ : 396.2145 .

\section{Chromoculatimine B (4)}

Colourless oil; $[\alpha]_{\mathrm{D}}-24\left(\right.$ c 0.03 in $\left.\mathrm{CHCl}_{3}\right) ; \delta_{\mathrm{H}}\left(\mathrm{CDCl}_{3}\right.$, $750 \mathrm{MHz})$ and $\delta_{\mathrm{C}}\left(\mathrm{CDCl}_{3}, 188 \mathrm{MHz}\right)$, see Tables 1 and 2 ; HR-ESI MS m/z 412.2467 [M+Na] ${ }^{+}$; calc. for $\mathrm{C}_{23} \mathrm{H}_{35} \mathrm{NO}_{4} \mathrm{Na}$ : 412.2458 .

\section{Aplyroseol-19 (5)}

Colourless oil; $[\alpha]_{\mathrm{D}}+9\left(c 0.03\right.$ in $\left.\mathrm{CHCl}_{3}\right) ; \delta_{\mathrm{H}}\left(\mathrm{CDCl}_{3}\right.$, $500 \mathrm{MHz})$ and $\delta_{\mathrm{C}}\left(\mathrm{CDCl}_{3}, 125 \mathrm{MHz}\right)$, see Tables 1 and 2 ; HR-ESI MS $m / z 517.2397[\mathrm{M}+\mathrm{Na}]^{+}$; calc. for $\mathrm{C}_{26} \mathrm{H}_{38} \mathrm{O}_{9} \mathrm{Na}$ : 517.2408.

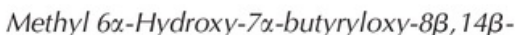

diformylpodocarpane-13 $\beta$-carboxylate (6)

Colourless oil; $[\alpha]_{\mathrm{D}}-19\left(\right.$ c 0.01 in $\left.\mathrm{CHCl}_{3}\right) ; \delta_{\mathrm{H}}\left(\mathrm{CDCl}_{3}\right.$, $900 \mathrm{MHz})$ and $\delta_{\mathrm{C}}\left(\mathrm{CDCl}_{3}, 225 \mathrm{MHz}\right)$, see Tables 1 and 2 ; HR-ESI MS $m / z 473.2508[\mathrm{M}+\mathrm{Na}]^{+}$; calc. for $\mathrm{C}_{25} \mathrm{H}_{38} \mathrm{O}_{7} \mathrm{Na}$ : 473.2510.

\section{Spongi-12-en-11,16-dione (22)}

Colourless oil; $[\alpha]_{\mathrm{D}}+44\left(c 0.02\right.$ in $\left.\mathrm{CHCl}_{3}\right)$, lit. $[\alpha]_{\mathrm{D}}+34.5(c$ 1.08 in $\left.\mathrm{CHCl}_{3}\right){ }^{[26]} \delta_{\mathrm{H}}\left(\mathrm{CDCl}_{3}, 750 \mathrm{MHz}\right) 6.54(1 \mathrm{H}, \mathrm{d}, J 3.5 \mathrm{~Hz}$, $\mathrm{H} 12), 4.54(1 \mathrm{H}, \mathrm{t}, J 9.2 \mathrm{~Hz}, \mathrm{H} 15 \beta), 4.16(1 \mathrm{H}, \mathrm{t}, J 9.2 \mathrm{~Hz}, \mathrm{H} 15 \alpha)$, $3.29(1 \mathrm{H}, \mathrm{td}, J 9.2,3.9 \mathrm{~Hz}, \mathrm{H} 14), 2.59(1 \mathrm{H}, \mathrm{dq}, J 12.8,3.1 \mathrm{~Hz}$, $\mathrm{H} 1 \beta), 2.11(1 \mathrm{H}, \mathrm{s}, \mathrm{H} 9), 1.72(1 \mathrm{H}, \mathrm{dq}, \delta 12.7,3.1 \mathrm{~Hz}, \mathrm{H} 7 \beta), 1.66$ $(1 \mathrm{H}, \mathrm{td}, J 13.7,3.5 \mathrm{~Hz}, \mathrm{H} 2 \alpha), 1.62(1 \mathrm{H}, \mathrm{m}, \mathrm{H} 6 \alpha), 1.55(1 \mathrm{H}, \mathrm{m}$, $\mathrm{H} 7 \alpha$ ), $1.42-1.41$ ( $3 \mathrm{H}, \mathrm{m}, \mathrm{H} 2 \beta, \mathrm{H} 6 \beta, \mathrm{H} 3 \beta), 1.17$ (1H, td, $J 13.4$, $4.1 \mathrm{~Hz}, \mathrm{H} 3 \alpha$ ), 1.15 (3H, s, Me-20), 0.96 (3H, s, Me-17), 0.88 $(3 \mathrm{H}, \mathrm{s}, \mathrm{Me}-18), 0.86(1 \mathrm{H}, \mathrm{dd}, J 12.4,2.1 \mathrm{~Hz}, \mathrm{H} 5), 0.85(3 \mathrm{H}, \mathrm{s}$, $\mathrm{Me}-19), 0.81(1 \mathrm{H}, \mathrm{m}, \mathrm{Hl} \alpha) ; \delta_{\mathrm{C}}\left(\mathrm{CDCl}_{3}, 188 \mathrm{MHz}\right) 199.4(\mathrm{Cl1})$, 168.8 (C16), 142.6 (C13), 130.4 (C12), 69.1 (C9), 67.1 (C15), 56.4 (C5), 52.6 (C14), 44.0 (C8), 42.1 (C3), 41.3 (C7), 39.7 (C1), 37.8 (C10), 33.7 (C4 and Me-18), 21.9(Me-19), $18.3(\mathrm{C} 2), 17.7$ (C6), 16.2 (Me-20), 15.7 (Me-17); HR-ESI MS m/z 339.1927 $[\mathrm{M}+\mathrm{Na}]^{+}$; calc. for $\mathrm{C}_{20} \mathrm{H}_{28} \mathrm{O}_{3} \mathrm{Na}: 339.1931$.

\section{Accessory Publication}

The Accessory Publication contains copies of representative NMR spectra, including the ${ }^{1} \mathrm{H}$ spectra of metabolites (1-6) in $\mathrm{CDCl}_{3}$, together with HMBC and NOESY data. The Accessory Publication is available on the Journal's website.

\section{Acknowledgements}

We thank the University of Queensland for the award of a University of Queensland Research Scholarship (UQRS) and a University of Queensland International Research Tuition Award (UQIRTA), the Australia Research Council for funding, and Mr. G. MacFarlane of the School of Chemistry and Molecular Biosciences, University of Queensland, for spectroscopic assistance. ScubaWorld Mooloolaba assisted with access to dive sites. Sample collection was carried out under permit from the Department of Primary Industries and Fisheries, Queensland. 


\section{References}

[1] G. Cimino, A. Fontana, M. Gavagnin, Curr. Org. Chem. 1999, 3, 327.

[2] M. Gavagnin, A. Fontana, Curr. Org. Chem. 2000, 4, 1201. doi: $10.2174 / 1385272003375798$

[3] R. J. Andersen, K. Desjardins, K. Woods, in Molluscs: from Chemoecological Study to Biotechnological Application 2006, pp. 277-301 (Eds G. Cimino, M. Gavagnin) (Springer: New York, NY)

[4] A. Fontana, in Biogenetic Proposals and Biosynthetic Studies on Secondary Metabolites of Opisthobranch Molluscs 2006, pp. 303-332 (Eds G. Cimino, M. Gavagnin) (Springer: New York, NY).

[5] A. Fontana, P. Cavaliere, N. Ungur, L. D'Souza, P. S. Parameswaram, G. Cimino, J. Nat. Prod. 1999, 62, 1367. doi:10.1021/NP9900932

[6] G. Cimino, S. De Rosa, S. De Stephano, G. Sodano, G. Villani, Science 1983, 219, 1237, doi:10.1126/SCIENCE. 219.4589.1237

[7] A. Fontana, A. Tramice, A. Cutignano, G. d'Ippolito, M. Gavagnin, G. Cimino, J. Org Chem. 2003, 68, 2405, doi:10.1021/JO02613/V

[8] H. Gaspar, A. Cutignano, T. Ferreira, G. Calado, G. Cimino, A. Fontana, J. Nat. Prod. 2008, 71, 2053. doi:10.1021/NP8004387

[9] S. A. Morris, E. D. de Silva, R. J. Andersen, Can. J. Chem. 1991, 69 , 768. doi:10.1139/V91-114

[10] M. Gavagnin, R. R. Vardaro, C. Avila, G. Cimino, J. Ortea, J. Nat. Prod. 1992, 55, 368. doi:10.1021/NP50081A014

[11] G. Cimino, A. Crispino, M. Gavagnin, G. Sodano, J. Nat. Prod. 1990, 53, 102. doi:10.1021/NP50067A013

[12] R. Puliti, M. Gavagnin, G. Cimino, C. A. Mattia, L. Mazzarella, Acta Crystallogr. 1992, 48C, 2145 .

[13] T. Miyamoto, K. Sakamoto, K. Arao, T. Komori, R. Higuchi, T. Sasaki, Tetrahedron 1996, 52, 8187, doi:10.1016/0040-4020(96) 00388-2

[14] T. F. Molinski, D. J. Faulkner, J. Org. Chem. 1986, 5l, 2601. doi: $10.1021 / \mathrm{JO} 00363 \mathrm{~A} 040$

[15] P. Karuso, B. W. Skelton, W. C. Taylor, A. H. White, Aust. J. Chem. 1984, 37, 1081. doi:10.1071/CH9841081

[16] S. K. Graham, M. J. Garson, P. V. Bernhardt, J. Chem. Crystallogr. 2010, 40, 468. doi:10.1007/S10870-009-9679-9

[17] T. F. Molinski, D. J. Faulkner, H. Cun-Heng, G. D. Van Duyne, J. Clardy, J. Org. Chem. 1986, 5I, 4564. doi:10.1021/JO00374A014

[18] S. C. Bobzin, D. J. Faulkner, J. Org. Chem. 1989, 54, 5727. doi:10.1021/ JO00285A019

[19] M. J. Schnermann, C. M. Beaudry, A. V. Egorova, R. S. Polishchuk, C. Sütterlin, L. E. Overman, Proc. Natl. Acad. Sci. USA 2010, 107, 6158. doi:10.1073/PNAS.1001421107
[20] K. W. L. Yong, A. A. Salim, M. J. Garson, Tetrahedron 2008, 64, 6733. doi: 10.1016/J.TET.2008.05.008

[21] R. P. Walker, D. J. Faulkner, J. Org. Chem. 1981, 46, 1098. doi:10.1021/ JO00319A012

[22] P. Karuso, W. C. Taylor, Aust. J. Chem. 1986, 39, 1629.

[23] P. Karuso, P. R. Bergquist, R. C. Cambie, J. S. Buckleton, G. R. Clark, C. E. F. Rickard, Aust. J. Chem. 1986, 39, 1643

[24] T. F. Molinski, D. J. Faulkner,J. Org. Chem. 1987, 52, 296. doi:10.1021/ JO00378A031

[25] M. R. Kernan, R. C. Cambie, P. R. Bergquist, J. Nat. Prod. 1990, 53 , 724. doi:10.1021/NP50069A034

[26] A. G. Gonzalez, D. M. Estrada, J. D. Martin, V. S. Martin, C. Perez, R. Perez, Tetrahedron 1984, 40, 4109. doi:10.1016/0040-4020(84) 85092-9

[27] F. J. Schmitz, J. S. Chang, M. B. Hossain, D. van der Helm, J. Org. Chem. 1985, 50, 2862. doi:10.1021/JO00216A010

[28] W. C. Taylor, S. Toth, Aust. J. Chem. 1997, 50, 895. doi:10.1071/ C96166

[29] M. B. Ksebati, F. J. Schmitz, J. Org. Chem. 1987, 52, 3766 doi: $10.1021 / \mathrm{JO00226A008}$

[30] E. Zubía, M. Gavagnin, G. Scognamiglio, G. Cimino, G. B. Giusto, J. Nat. Prod. 1994, 57, 725. doi:10.1021/NP50108A007

[31] In the ${ }^{1} \mathrm{H} \mathrm{NMR}$ data for compound 7 of ref. [20], the signal for $\mathrm{H} 13$ is described as a td $(J 12.8,62 \mathrm{~Hz})$; the revised description should be as a $\mathrm{dt}$ since there is only one $12.8 \mathrm{~Hz}$ coupling.

[32] B. D. Morris, M. R. Prinsep, J. Nat. Prod. 1999, 62, 688. doi:10.1021/ NP980410P

[33] P. M. Imamura, M. G. Sierra, E. A. Rúveda, J. Chem. Soc. Chem. Commun. 1981, 734. doi:10.1039/C39810000734

[34] T. W. Hambley, W. C. Taylor, S. Toth, Aust. J. Chem. 1997, 50, 391. doi: $10.1071 / \mathrm{C} 96162$

[35] R. A. Keyzers, P. T. Northcote, M. T. Davies-Coleman, Nat. Prod. Rep. 2006, 23, 321. doi:10.1039/B503531G

[36] E. Manzo, M. Gavagnin, M. J. Somerville, S.-C. Mao, M. L. Ciavatta, E. Mollo, P. J. Schupp, M. J. Garson, Y.-W. Guo, G. Cimino, J. Chem. Ecol. 2007, 33, 2325. doi:10.1007/S10886-007-9387-X

[37] N. Coleman, 1001 Nudibranchs: Catalogue of Indo-Pacific Sea Slugs 2001, p. 72 (Neville Coleman's Underwater Geographic Pty Ltd: Springwood, QLD). 
Structures and Anatomical Distribution of Oxygenated Diterpenes in the Australian Nudibranch Chromodoris reticulata

\section{ORIGINALITY REPORT}

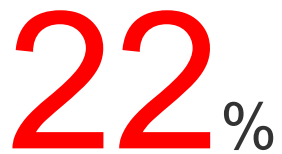

SIMILARITY INDEX

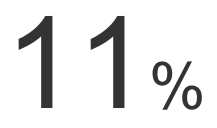

INTERNET SOURCES

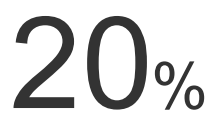

PUBLICATIONS
$0 \%$

STUDENT PAPERS

PRIMARY SOURCES

1 www.mdpi.com

Internet Source

2 hellas-orthodoxy.blogspot.gr

Internet Source

3 www.raci.org.au

Internet Source

4 Steven V. Ley. "The Synthesis of Azadirachtin:

A Potent Insect Antifeedant", Chemistry - A

European Journal, 11/26/2008

Publication

5 Chemistry of Plant Natural Products, 2015.

Publication

7 Gray, C.A.. "An improved synthesis of rhinocerotinoic acid", Tetrahedron, 20030106 
8 Mutai, C.. "Cytotoxic lupane-type triterpenoids from Acacia mellifera", Phytochemistry,

200404

Publication

9 open.library.ubc.ca

10 Cheng, Shi-Yie, Shang-Kwei Wang, Shu-Fen Chiou, Chi-Hsin Hsu, Chang-Feng Dai, Michael

Y. Chiang, and Chang-Yih Duh. "Cembranoids

from the Octocoral Sarcophyton ehrenbergi",

Journal of Natural Products, 2010.

Publication

11

Nagashima, F.. "Novel cytotoxic kaurane-type diterpenoids from the New Zealand Liverwort Jungermannia species", Tetrahedron, 20050509

Publication

\section{2}

Jung, M.E.. "Approaches to the synthesis of arisugacin A", Tetrahedron, 20070430

Louise C. Forster, Gregory K. Pierens, Andrew M. White, Karen L. Cheney, Pradeep

Dewapriya, Robert J. Capon, Mary J. Garson. "

Cytotoxic Spiroepoxide Lactone and Its

Putative Biosynthetic Precursor from ", ACS

Omega, 2017 
Mohamad, K.. "Dammarane triterpenes and

pregnane steroids from Aglaia lawii and A.

tomentosa", Phytochemistry, 199908

Publication

$15 \quad$ www.jstage.jst.go.jp

Internet Source

16 Geonseek Ryu, Shigeki Matsunaga, Nobuhiro

Fusetani. " Three New Cytotoxic

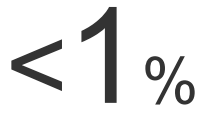

Sesterterpenes from the Marine Sponge cf. ",

Journal of Natural Products, 1996

Publication

17 Huang, Sheng-Xiong, Qin-Shi Zhao, Gang Xu, Wei-Lie Xiao, Rong-Tao Li, Ai-Jun Hou, Shu-

Lin Peng, Li-Sheng Ding, and Han-Dong Sun.

"ent-Kaurane Diterpenoids from Isodon

albopilosus", Journal of Natural Products,

2005.

Publication

18

Germonprez, N.. "New pentacyclic triterpene

saponins with strong anti-leishmanial activity

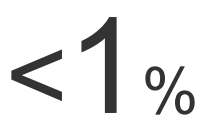

from the leaves of Maesa balansae",

Tetrahedron, 20040101

Publication

19 gallery.women.qld.gov.au

Internet Source

Culioli, G.. "A lupane triterpene from 
frankincense (Boswellia sp., Burseraceae)",

Phytochemistry, 200302

21 kb.psu.ac.th

22 Allevi, P.. "The first example of C-

glucopyranosides", Chemistry and Physics of

Lipids, 199003

Publication

23

Yamada, Hidetoshi, and Mugio Nishizawa.

"Synthesis and Structure Revision of Intensely

Sweet Saponin Osladin", The Journal of

Organic Chemistry, 1995.

Publication

24

Yang, X.W.. "Isolation, structure, and

bioactivities of abiesadines A-Y, 25 new

diterpenes from Abies georgei Orr", Bioorganic

\& Medicinal Chemistry, 20100115

Publication

25

Faviola Cardoso-Martínez, José M. de la Rosa,

Ana R. Díaz-Marrero, José Darias et al.

"Oxysterols from an octocoral of the genus

Gorgonia from the eastern Pacific of Panama",

RSC Advances, 2016

Publication 
Manuel Arnó, Liliana Betancur-Galvis, Miguel

A. González, Jelver Sierra, Ramón J.

Zaragozá. "Synthesis and cytotoxic activity of

novel C7-Functionalized spongiane diterpenes",

Bioorganic \& Medicinal Chemistry, 2003

Publication

28

Chen Wang, Ping Wu, Shuai Tian, Jinghua

Xue, Liangxiong Xu, Hanxiang Li, Xiaoyi Wei. "

Bioactive Pentacyclic Triterpenoids from the

Leaves of ", Journal of Natural Products, 2016

Publication

29 Hernandez-Guerrero, C.J.. "Sesterterpene

metabolites from the sponge Hyatella intestinalis", Tetrahedron, 20060605

Publication

30

Zhang, Yuliang, Ajay K. Pandey, Chen Tao,

Yuan Fang, Hui Jin, Paul L. Burn, and Paul

Meredith. "Spectral response tuning using an

optical spacer in broad-band organic solar

cells", Applied Physics Letters, 2013.

Publication

Virgili, M.. "Chiral (E,E)-1,4-dialkoxy-1,3-

butadienes. 2. Conformational studies and

Diels-Alder reactions with symmetric

dienophiles", Tetrahedron, 19990326

Publication

Pınar Akbay. "Novel Antileukemic Sterol 
32 Glycosides from Ajuga salicifolia", Helvetica

Chimica Acta, 07/2002

Publication

33 Calcul, L.. "Novel alkaloids of the aaptamine class from an Indonesian marine sponge of the genus Xestospongia", Tetrahedron, 20030818 Publication

34 Mary J. Garson. "Marine Natural Products as Antifeedants", Elsevier BV, 2010 Publication

35

Shi-Yie Cheng. "Three new eudesmanoids from the Formosan soft coral Nephthea erecta", Journal of Asian Natural Products Research,

\section{$11 / 2009$}

Publication

36 Catal $\tilde{A}_{j n}$, Luis Espinoza, Karen CatalÃ $j n$

MarÃn, HÃ@ctor Carrasco Altamirano, Mauricio

Cuellar Fritis, and MarÃa Cristina Chamy.

"Oxidative Degradations of the Side Chain of

Unsaturated Ent-labdanes. Part II", Molecules,

2007.

Publication

37 Baba, T.. "Synthesis of the JKLM-ring fragment of ciguatoxin", Tetrahedron, 20030825

Isaka, Masahiko, Panida Chinthanom, Malipan Sappan, Rungtiwa Chanthaket, J. Jennifer 
Luangsa-ard, Samran Prabpai, and Palangpon Kongsaeree. "Lanostane and Hopane

Triterpenes from the Entomopathogenic

Fungus Hypocrella sp. BCC 14524", Journal of

Natural Products, 2011.

Publication

39 Jung, M.E.. "Synthetic approach to analogues of betulinic acid", Tetrahedron, 20061002

Publication

40 Shi-Hui Dong. "Triterpenoids from Melia toosendan", Helvetica Chimica Acta, 02/2012 Publication

41 Leandro N. Monsalve. "Enzyme-Catalysed Transformations ofent-Kaurane Diterpenoids", European Journal of Organic Chemistry, 05/2005

Publication 42 WwW.acgpubs.org

43 Banwell, M.G.. "Chemoenzymatic total syntheses of the linear triquinane-type natural products (+)-hirsutic acid and (-)-complicatic acid from toluene", Tetrahedron, 20070709 Publication

Ascari, Jociani, Maria Amélia Diamantino

Boaventura, Jacqueline Aparecida Takahashi, Rosa Durán-Patrón, Rosario Hernández-Galán, 
Antonio J. Macías-Sánchez, and Isidro G.

Collado. "Phytotoxic Activity and Metabolism of

Botrytis cinerea and Structure-Activity

Relationships of Isocaryolane Derivatives",

Journal of Natural Products, 2013.

Publication

45

Abdul Majid Ayatollahi. "New myrsinane-type diterpenoids from Euphorbia aellenii Rech. $f$.

with their immunomodulatory activity", Journal

of Asian Natural Products Research, 12/2010

Publication

46 Sword, Ryan, Steven O'Sullivan, and John A.

Murphy. "A Novel Organic Electron Donor

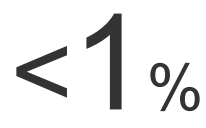

Derived from N-Methylisatin*", Australian

Journal of Chemistry, 2013.

Publication

47

Watanabe, S.. "Caged compounds with a

steroid skeleton: synthesis, liposome-formation

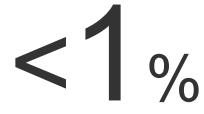
and photolysis", Tetrahedron, 20020225

Publication

48

Ying Zhu. "New Triterpenoid Saponins and

Neolignans from Morina kokonorica", Helvetica

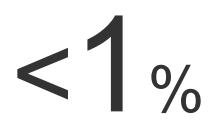

Chimica Acta, 03/2009

Publication

www.knopers.net

Internet Source

Manuel Arnó. "1H and13C NMR assignments 
50 and conformational analysis of some tetracyclic compounds with a bicyclo[4.2.0]octane ring system", Magnetic Resonance in Chemistry, 08/1998

Publication

51 www.freepatentsonline.com Internet Source

52 Ma, Ning, Hai-Feng Tang, Feng Qiu, Hou-Wen

Lin, Xiang-Rong Tian, and Min-Na Yao.

"Polyhydroxysteroidal Glycosides from the

Starfish Anthenea chinensis", Journal of

Natural Products, 2010.

Publication

53 www.google.com

Internet Source

54 Jun-Feng Wang. "Three New Diarylheptanoids from Myrica nana", Helvetica Chimica Acta,

08/2009

Publication

55

Tian, Ye, Wendong Xu, Chenggen Zhu, Sheng Lin, Ying Guo, and Jiangong Shi. "Diterpenoids with Diverse Skeletons from the Roots of Euphorbia micractina", Journal of Natural Products, 2013.

Publication

Julien Rouleau, Bogdan I. lorga, Catherine Guillou. "New potent human 
acetylcholinesterase inhibitors in the tetracyclic triterpene series with inhibitory potency on amyloid $\beta$ aggregation", European Journal of Medicinal Chemistry, 2011

Publication

57 digital.library.adelaide.edu.au Internet Source

58 María C. de la Torre. "Diversity Oriented Synthesis of Hispanane-like Terpene Derivatives from (R)-(+)-Sclareolide", Chemistry - A European Journal, 06/06/2005 Publication

\section{9}

Mitsui, K.. "Triterpenoids from Cedrela sinensis", Tetrahedron, 20051031

Publication

60 Seketsu Fukuzawa, Shigeki Matsunaga, Nobuhiro Fusetani. " Isolation of $13 \mathrm{New}$

Ritterazines from the Tunicate and Chemical

Transformation of Ritterazine B ", The Journal

of Organic Chemistry, 1997

Publication

61 www.google.it

Internet Source

62 Ponomarenko, Ludmila P., Anatoly I.

Kalinovsky, Shamil Sh. Afiyatullov, Michail A.

Pushilin, Andrey V. Gerasimenko, Vladimir B. 
Krasokhin, and Valentin A. Stonik. "Spongian

Diterpenoids from the Sponge Spongia

(Heterofibria) sp.", Journal of Natural Products,

2007.

Publication

63

Tadashi Nakata. "SmI2-induced cyclizations and their applications in natural product synthesis", The Chemical Record, 05/25/2010

Publication

64 comicstrades.me

Internet Source

65 pastel.archives-ouvertes.fr

Internet Source

66 Tang, Pei, Qi-Feng Chen, Ling Wang, QiaoHong Chen, Xi-Xian Jian, and Feng-Peng

Wang. "New reactivities of deltaline analogs: an

efficient O-demethylation at C-1 and an

unusual extrusion of the C-14 atom",

Tetrahedron, 2012.

Publication

67

Emiliano Manzo. "Chemistry of Glossodoris

Nudibranchs: Specific Occurrence of 12-Keto

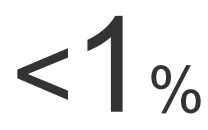

Scalaranes", Journal of Chemical Ecology,

$12 / 05 / 2007$

Publication

Abdel-Sattar, E.. "Penicillosides A-C, C-15 oxypregnane glycosides from Caralluma 
penicillata", Phytochemistry, 200108

Publication

69 Marina Grinco. "Superacid-Catalyzed

Cyclization of Methyl (6Z)-Geranylfarnesoates",

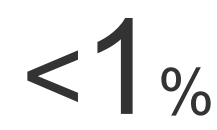
Helvetica Chimica Acta, 06/2007

Publication

70 Che-Ping Chuang. "Manganese (III) Acetate Initiated Oxidative Free Radical Reaction of 3Heteroaryl Substituted Malonates", Synthetic Communications, 6/1/1994 Publication

71

David Hart. "Tert-Butyldiphenylsilylmethyl

Triflate: Preparation and Dipolar Cycloaddition Reactions of 1-(Tert-Butyldiphenylsilylmethyl)6-Cyano-4-Methyl-1,2,5,6-Tetrahydropyridine", Synthetic Communications, 9/1/2000 Publication

Li, Hou-Jin, Taro Amagata, Karen Tenney, and Phillip Crews. "Additional Scalarane Sesterterpenes from the Sponge Phyllospongia papyracea", Journal of Natural Products, 2007. Publication

73

Chamy, M.C.. "Diterpenoids from calceolaria dentata", Phytochemistry, 199512 Publication 
76 Chan, B.K.H.. "An effective method for the

preparation of mono $\mathrm{N}$-alkyl derivatives of 1,1'-

bis(6,7-dimethoxy-1,2,3,4-

tetrahydroisoquinoline)", Tetrahedron,

20060515

Publication

77 Terauchi, T.. "Synthesis and pharmacological

profile of serofendic acids A and B", Bioorganic

\& Medicinal Chemistry, 20071115

Publication

78

Antonio Abad, Consuelo Agulló, Ana C. Cuñat,

Ana Belén García. "Syntheses of oxygenated

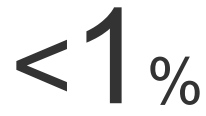

spongiane diterpenes from carvone. Synthesis

of dorisenone C", Tetrahedron, 2005

Publication

79

Ahmed H. El-Desoky, Hikaru Kato, Ippei

Kagiyama, Yuki Hitora et al. " Ceylonins A-F,

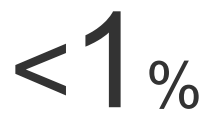

Spongian Diterpene Derivatives That Inhibit

RANKL-Induced Formation of Multinuclear

Osteoclasts, from the Marine Sponge ", Journal

of Natural Products, 2016

Publication

Nakamura, Y.. "Enantio-differential approach to identify the target cell for glucosyl jasmonatetype leaf-closing factor, by using fluorescence- 
labeled probe compounds", Tetrahedron, 20060911

Publication

81 Chou, Bo-Hon, Li-Ming Yang, Shwu-Fen

Chang, Feng-Lin Hsu, Li-Hsuan Wang, Wen-

Kuang Lin, Pan-Chun Liu, and Shwu-Jiuan Lin.

"Transformation of Isosteviol Lactam by Fungi

and the Suppressive Effects of Its Transformed

Products on LPS-Induced iNOS Expression in

Macrophages", Journal of Natural Products,

2011.

Publication

82 Claudia Osterhage, Gabriele M. König, Ulrich

Höller, Anthony D. Wright. " Rare

Sesquiterpenes from the Algicolous Fungus ",

Journal of Natural Products, 2002

Publication

83

Hua-Ping Zhang. "Note", Journal of Asian

Natural Products Research, 2/1/2005

Publication

Cossy, Janine, Catherine Willis, Véronique

Bellosta, and Samir BouzBouz.

"Enantioselective Allyltitanations and

Metathesis Reactions. Application to the

Synthesis of Piperidine Alkaloids (+)-Sedamine and (-)-Prosophylline", The Journal of Organic

Chemistry, 2002.

Publication 


\section{5 www.senacyt.gob.pa}

86 Cui, J.. "Phragmalin-type limonoids from the mangrove plant Xylocarpus granatum",

Phytochemistry, 200510

Publication

87

"Handbook of Marine Natural Products",

Springer Nature America, Inc, 2012

Publication

88 pac.iupac.org

Internet Source

89 Dhital, S.. "Relationship between granule size and in vitro digestibility of maize and potato starches", Carbohydrate Polymers, 20100905 Publication

90

Marcos, I.S.. "Synthetic studies towards

picrasane quassinoids", Tetrahedron, 20070305

91

(+)-Paeonilide and Confirmation of its Absolute

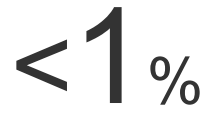

Configuration", Synlett, 05/2006

Publication

"Molluscs", Springer Nature America, Inc, 2006

Publication

Chang, Shwu-Fen, Li-Ming Yang, Feng-Lin 
Hsu, Ju-Yin Hsu, Jia-Horng Liaw, and ShwuJiuan Lin. "Transformation of Steviol-16a,17epoxide by Streptomyces griseus and

Cunninghamella bainieri", Journal of Natural Products, 2006. 


\section{Structures and Anatomical Distribution of Oxygenated Diterpenes in the Australian Nudibranch Chromodoris reticulata}

GRADEMARK REPORT

FINAL GRADE

10

PAGE 1

PAGE 2

PAGE 3

PAGE 4

PAGE 5

PAGE 6

PAGE 7

PAGE 8

PAGE 9
GENERAL COMMENTS

Instructor 